\title{
Factors That Influence the Intentions to Revisit Korea of Vietnamese Tourists
}

\author{
Xuan Truong NGUYEN* \\ Received: February 9, 2020 Revised: February 24, 2020 Accepted: March 1, 2020.
}

\begin{abstract}
The study investigates the influences of different factors on revisit intention to Korea of Vietnamese tourists. A mixed-method including qualitative and quantitative methodologies were utilized. A focus group of 9 experts was carried out for reviewing and exploring different factors and the conceptual model. An in-depth interview with 19 participants was developed with an aim to develop and correct measurement items. The conceptual model was tested and developed using data collected by a questionnaire, from a sample of 473 respondents, who have visited Korea by both electronic and paper surveys with non-probability and convenience sampling techniques. The questionnaire in this research applied a 5-point Likert scale and was distributed both electronically using Google form and by questionnaire paper. The Bootstrap model was used for estimating the model parameters for retesting the reliability of the estimates. Factor analysis and Structural Equation Modelling are employed to analyze the data. Results showed that 427 tourists traveling by groups organized by travel companies and 46 tourists traveling on their own. The reliability, tangibility, empathy, and assurance had influences on tourists' intention to revisit a destination, especially through satisfaction mediating construct. Destination image, self-congruity, and the emergence of Hallyu had influences intension revisit through attitude and tourist motivation.
\end{abstract}

Keywords: Revisit Intention, Hallyu, Destination Image, Satisfaction, Outbound Tourists, Vietnam.

JEL Classification Code: M16, M30, M31

\section{Introduction}

The tourism industry was a service sector that had been recognized to give a greater impact on the economy of a nation. In the tourism literature, many scholars had acknowledged the importance of studying the relationships of variables such as travel motivation, destination image, visitor satisfaction, revisit intention and destination loyalty (Huang \& Hsu, 2009; Kozak, 2001; San Martín \& Del Bosque, 2008). Revisit intention and the relationship between service quality and visitor satisfaction, destination image, self-congruity, Hallyu had also

*First Author and Corresponding Author. Dean, Marketing Department, University of Finance - Marketing, Vietnam [Postal Address: 2/4 Tran Xuan Soan Street, Tan Thuan Tay Ward, District 7, Ho Chi Minh City, 72910, Vietnam] Tel: (+84) 913905997 Email: ts.truong@ufm.edu.vn

(c) Copyright: The Author(s)

This is an Open Access article distributed under the terms of the Creative Commons Attribution Non-Commercial License (http://Creativecommons.org/licenses/by-nc/4.0/) which permits unrestricted noncommercial use, distribution, and reproduction in any medium, provided the original work is properly cited. received considerable academic attention in the past few years. The most popular and widely used instruments that had been conducted by many researchers to analyze the concepts of service quality and customer satisfaction in the service industry were the SERVQUAL model. Researchers had put their interest and emphasis on service quality as it had significantly influenced not only business performance, customer satisfaction, employee retention, profitability but also customer loyalty measurement, high return on investment and competitive advantage (Kim \& Lee, 2010).

Vietnamese tourists visit Korea to experience its uniqueness. They are attracted by a beautiful nature which is a reputation for the movies industry, art and crafts, musical and cultural activities, habitat and vernacular architecture, historical significance, traditional food and activities, and special phenomena. However, the exact relationship between service quality and other factors and revisit intention has still been shrouded with uncertainty. On the basis of inheriting the previous research, the relationship between service quality, customer satisfaction, some other factors and revisit intention to Korea of Vietnamese tourists was 
investigated in this study. The findings provide Korean firms and governments with data and information, which assists the process of researching and carrying out appropriate strategies.

\section{Literature Review and Hypotheses}

\subsection{Service Quality (SQ)}

Service quality played an important role and had received increasing attention in the tourism literature (Hudson, Hudson, \& Miller, 2004). Many researchers have also investigated the relationship between service quality, tourists' satisfaction and their intention to revisit. According to Atilgan, Akinci, and Aksoy (2003), service quality had become a great predictor of outcomes, such as customer satisfaction. Tourist satisfaction was considered very important, as it was influential in the choice of destinations and revisit intention (Kozak \& Rimmington, 2000). Bowen and Clarke (2002) stated that determining the impact of service quality on visitor satisfaction allowed tourism managers to provide the best possible service. Following the SERVQUAL model (Parasuraman, Zeithaml, \& Berry, 1988) and SERVPERF model (Cronin \& Taylor, 1992), five service quality dimensions were tangibility, reliability, responsiveness, assurance, and empathy. Gumussoy and Koseoglu (2016) found out that these five elements were significantly correlated with tourist satisfaction.

Firstly, Reliability (RE) was referred to as the ability to perform the promised service dependably and accurately. Reliability was the most important factor in conventional service (Parasuraman et al., 1988., Zeithaml, Bitner, \& Gremler, 2006). Reliability had a significantly positive effect on customer satisfaction, (Sriyam, 2010). Secondly, Tangibility (TA) was the physical facilities, equipment, and appearance of personnel. Ananth, Ramesh, and Prabaharan (2010) considered tangibility as modern looking equipment and physical facilities, such as well-dressed employees and visually-appealing materials. Tangibility factors influenced not only customers' perceptions but also their loyalty and could bring about more profits (Abdullah, Razak, Marzuki, \& Jaafar, 2017). Research results of Pusiran and Xiao (2013), showed that tangibility factors influenced customer satisfaction. The taste of the food showed a positive relationship with the level of satisfaction of tourists (Nguyen, Dang, \& Ngo, 2019). Thirdly, Responsiveness (RE) was referred to as the willingness or readiness of employees to provide service. It involved timeliness of services.

According to Kumar, Kee, and Manshor (2009), responsiveness involved understanding the needs and wants of customers, opening inconvenient hours, giving individual attention, and paying attention to problems and customers. Moreover, Assurance (AS) was defined as the knowledge and courtesy of employees and their ability to inspire trust and confidence. Assurance meant polite and friendly staff, provision of financial advice, interior comfort, eases of access to account information and knowledgeable and experienced management team (El Saghier \& Nathan, 2013). Last but not least, Empathy (EM) was used to describe the caring and individual attention given to customers, which involved giving individual attention; opening at convenient business hours; showing best interest at heart and understanding customers' specific needs (Ananth et al., 2010). Based on the relationship between customer satisfaction with reliability, tangibility, empathy, responsiveness, and assurance shown above, this study proposed five hypotheses as followed:

H1: Reliability has a positive impact on customer satisfaction.

H2: Tangibility has a positive impact on customer satisfaction.

H3: Responsiveness has a positive impact on customer satisfaction.

H4: Empathy has a positive impact on customer satisfaction.

H5: Assurance has a positive impact on customer satisfaction.

\subsection{Price (PR)}

Price was something measurable that came in several levels and types, such as affordable price, fair price, discounted price, competitor price, and price suitability (Kotler \& Keller, 2012). Price included all the costs that visitors needed to pay to obtain benefits from products or services they experienced in one destination (Wirtz \& Lovelock, 2016). Cost affected customer expectations with the service level (Zeithaml et al., 2006). According to Williams and Soutar (2009), tourists perceived positive value when the received benefits were greater than the costs incurred. Several studies also confirmed the significant effect of perceived price fairness on customer satisfaction (Yieh, Chiao, \& Chiu, 2007).

In the service context, customer satisfaction was the key factor affecting service loyalty. The satisfied customer was less sensitive towards the price, purchase more products, were less influenced by the rivals and were more loyal. Noh, Lee, and Hwang (2017) proposed that satisfaction was an important antecedent to visitors' attitudinal loyalty. Wang, $\mathrm{Wu}$, and Yuan (2010) explored that visitors' intentions to revisit depended on their experiences and satisfaction. Previous researches also suggested that perceived costs negatively affect perceived value. Hence, it is hypothesized 
that:

H6: Price has a negative influence on customer satisfaction.

\subsection{Self-Congruity (SC)}

There had been various definitions related to selfcongruity. Kressmann, Sirgy, Herrmann, Huber, Huber, and Lee (2006) defined self-image congruence as the match between consumers' self-concept and user image of a given product, brand, store, etc. Self-congruity as individuals, all the products have their own personal images that were defined by price, physical aspects, and advertisements (Jamal \& Goode, 2001). When it came to self-congruity, Sirgy (1982) mentioned the extension of mismatch or match among individual's perceptions of the brand and product. The congruence between perceived image and self-image of a product could impact customers' preference and thus, resulted in buying behavior. The self-congruity concept was developed in social psychology and had been useful to investigate consumers' behaviors in recent years. Kressmann et al. (2006) used self-congruity as a topic for brand loyalty and brand preference researches.

Usakli and Baloglu (2011) showed that a destination brand personality would have a positive influence on the intention to recommend and return. Sirgy and $\mathrm{Su}$ (2000) found that self-congruity had a positive impact on tourist behaviors. Self-congruity was supposed to engender a motivational tendency which in turn biased the interpretation of functional attributes (Kressmann et al., 2006). Beerli, Meneses, and Gil (2007) stated that selfcongruity influenced leisure tourism. Applying the above results, it could be assumed that self-congruity meant that the visitors appreciated the destination image and were motivated about how they felt. Therefore, the hypothesis is as follows:

H7: There is a significantly positive relationship between self-congruity and tourism motivation.

\subsection{Destination Image (DI)}

Destination image had been one of the most popular research topics in the tourism academic literature (Pike \& Page, 2014). Destination represented the ultimate end of tourism (Leiper, 1979). In this research, destination image was defined as a general impression on the tourist destination and divided into the cognitive image and emotional image. Destination image could be interpreted as a pull factor that had an influence on whether tourists selected or avoided a place to visit (Gartner, 1994). According to Kim (2014), destination image was a favorable image of a destination formed by a combination of destination's attributes (e.g., beautiful landscape, shopping opportunities, cultural exchange, infrastructure, safety, and activities). Perhaps the most comprehensive definition was the one provided by Echtner and Ritchie (1993), which defined the destination image based on three dimensions: attributes-holistic, functional-psychological, and common-unique. They indicated that past definitions were too vague and thus were unlikely to be effective. The results of several studies suggested that the destination image positively influenced the visit intention (Phau, Quintal, \& Shanka, 2014).

Huang and Hsu (2009) indicated that destination image was an important factor attracting an individual to visit and motivate revisit. Gallarza, Saura, and Garcia (2002) stated that the destination image had a strong impact on tourist behavior. It also had a great impact on consumer evaluations (Herrero, San, \& Collado, 2017). Destination image positively affected tourists' attitudes toward places they might visit (Phillips, Asperin, \& Wolfe, 2013). Some studies had explored tourist's revisit intention to predict and explain tourists' engagement in diverse types of tourism or visit different destinations. Based on the previous literature, this study investigated the relationships between destination image and attitudes toward future revisit. Hence, the hypothesis proposed is:

H8: Destination image positively influences attitude toward a future revisit.

\subsection{Hallyu (HA)}

The Hallyu was a Korean cultural production trend that comprised all Korea-related fields such as K-pop, K-drama, $\mathrm{K}$-movies, K-hi-tech-lifestyle, K-culture, together with $\mathrm{K}$ cuisine, literature and traditional language. According to Kim (2015), Hallyu 1.0 emerged with K-drama exports in the late $1990 \mathrm{~s}$, then came Hallyu 2.0 with K-music, Hallyu 3.0 with K-culture, and Hallyu 4.0 with K-style. Hallyu had played an important role in the steady increase of foreign tourism in Korea and increased the purchase of a related product such as cosmetics, fashion, and Korean cuisine by foreign customers (Yu, Kim, \& Kim, 2012). Many previous studies proved that the Korean Wave also has positive effects on exports of Korean products and increased tourism (Lee, 2015). Kim and Richardson (2003) had identified the possibilities that good movies and dramas could be a driving force behind tourism.

Urry (1990) stated that the driving force to see famous places in movies or dramas was termed as tourist 'gaze'. The tourist went to famous destinations in order to gaze filming locations connected with movies, music or novels. There was a positive and significant relationship between Hallyu and attitude toward Korean products and actual 
purchase (Nguyen, 2018; Nguyen, 2019). In 2017, there were 220,675 Vietnamese tourists to Korea for tourism purposes, 31.8\% higher than that of 2016 (Korea Tourism Organization, 2018). Vietnamese tourists have been influenced by Hallyu and thus, have been likely to decide to travel to Korea. Hence, hypothesis 8 is proposed as follows.

H9: Hallyu positively affects attitude toward future revisits to Korea.

\subsection{Attitude (AT)}

Attitude defined the reviews, thoughts and relatively consistent tendencies of humans against an object or an idea. It put humans into the framework to think about things they liked or did not. Consumers often bought when they had a positive attitude toward the product or service. The theory of reasoned action (TRA) and the theory of planned behavior (TPB) were developed focusing on trust and attitudes as determinants of consumer buying behavior. Attitude had long been among the most important and fervently investigated factors in consumer behavior research. The attitude was one of the critical constructs in understanding tourism motivation and behavior and tourist's attitude toward an object was determined by his or her felt needs and value system (Gnoth, 1997). The factors influencing the travel behavior of tourists included variables motivating them, their attitudes and various situational factors (Venkatesh, 2006). Attitudes played an important role in the formation of travel motivation, supporting the proposition that attitudes could influence tourism behavior (Sirgy \& Su, 2000; Luo \& Deng, 2008). Attitudes affect tourism motivation, leading to the proposal of the hypothesis:

H10: Attitude positively influences tourism motivation.

\subsection{Tourism Motivation (TM)}

The motivation was conceptually viewed as a state of need, a condition that served as a driving force to display different kinds of behavior toward certain types of activities, developing preferences, arriving at some expected satisfactory outcome (Backman, 1989). Motivation had been recognized by tourism scholars as an important variable in explaining tourist behavior. Motivations surfaced when a tourist wanted to satisfy a need or want and this could be seen as a very important variable in relation to their travel decisions and their satisfaction (Chang, 2007; Correia, do Valle, \& Moço, 2007). Motivation had been demonstrated as a mediator of the relationship between destination image and visit intention (Phillips \& Jang, 2007). According to George (2004) and
March and Woodside (2005), travel motivations could be considered as one of the most important psychological influences of tourist behavior. Correia et al. (2007) identified the motivations for traveling to exotic destinations to consist of knowledge, facilities, leisure, socialization, landscape features, and core attractions.

On the other hand, Chang (2007) indicated that the motivation for package tour travelers were: relaxation and pleasure, social relationships, sociopsychological needs, and socioeconomic factors. Kim (2012) stated that the motivation for tourism was the power shown by tourist action. This motivation of tourism affected directly and indirectly to satisfy the needs of a decision-maker at the action of making a decision of traveling. The motivation of tourism was divided into Push Factor promoted by the inner motivation of tourists themselves, and Pull Factor allured by the attribute of a tourist destination.

Mill and Morrison (1985) classified the motivation of tourism into 7 motivations such as rest motivation, safety motivation, love motivation, self-esteem motivation, true motivation, knowledge-seeking motivation, and beauty motivation. According to Noh, Lee, and Hwang (2017), motivation to offer information had a significant effect mainly on intentions to recommend. In addition, the motivation to store records had a significant effect on recommendation intentions. The specific hypothesis to be tested is:

H11: Tourism motivation positively influences revisit intention.

\subsection{Satisfaction (SA)}

Zeithaml et al. (2006) stated that customer satisfaction related to a specific transaction (the difference between predicted service and perceived service) in contrast with attitudes. In terms of tourist satisfaction, a number of theories had been proposed including the expectation and disconfirmation theory, the equity theory, the norm theory and the perceived overall performance theory (Yoon \& Uysal, 2005). Kozak and Rimmington (2000) stated that tourist satisfaction was considered to be very important, as it was very influential in the choice of destinations, the consumption of products and services, and the tourists' decision to revisit. Service quality had a positive influence on tourist satisfaction and future behavioral intentions (Canny, 2013).

Gour and Theingi (2009) found that passenger satisfaction with service-quality dimensions was very important in explaining behavioral intentions. On the other hand, customer satisfaction was defined as the extent of pleasure or contentment level felt by the visitors as a result of the experience of consuming a service (Severt, 2007). In 
the tourism context, consumers were deemed to attain satisfaction when they perceived experiences services that were beyond their expectations (Aliman, Mohamed Hashim, Mohd Wahid, \& Harudin, 2016). state of emotion after they experienced their tour (Sanchez, Callarisa, Rodriguez, \& Moliner, 2006). Family restaurant users' satisfaction had a positive influence on brand reliability to be significant (Sung, Kim, \& Youn, 2014). Customer satisfaction was one area researched a lot due to its importance in determining the success and the continued existence of a tourism business (Gursoy, McCleary, \& Lepsito, 2007). In the tourism literature, it had generally been accepted that when the tourists felt satisfied with services, products, and other resources provided by tourism destinations, they tend to increase their revisit intention, visits as well as positive word of mouth effects to their relatives and/or colleagues. Tourist satisfaction positively influenced behavioral intentions in the future (Kim, 2012). The study then derived hypothesis:

H12: There is a significantly positive relationship between tourist satisfaction and revisit intention.

\subsection{Revisit Intention (RI)}

Revisit intention was defined as the intention of coming back to or visit a particular place again. The first to reveal the importance of repeat travelers to destinations was Gitelson and Crompton (1984). They found out that many destinations relied heavily on the visit to repeat visitors. According to Um, Chon, and Ro (2006), tourist revisits intention had been considered an extension of satisfaction. In current years, the concept of tourist's revisit intentions has received growing attention from several researchers.
In tourism studies, customer satisfaction was the visitor's

Repeated visitors were more likely than first-time visitors to return to the same destination in the future (Kozak, 2001). Gitelson and Crompton (1984) and Sampol (1996) confirmed that repeated tourists were expected to be more likely than first-timers to choose the same destination for their future visits. Visitors tend to repeat a destination when they feel satisfied with the particular attributes during their first visit (Kozak, 2001). Although satisfaction with a particular destination was a factor influencing repeat visitations, visitors could not return to the same destination because they preferred to discover other places in their next holiday (Gitelson \& Crompton, 1984). An overview of the above research demonstrated that tourist intention revisit was considered a valuable concept in the tourism industry. Revisit intention depends on some constructs.

\section{Conceptual Model}

The relationship between factors and revisit intention has received considerable attention in academic literature. In this study, we developed a conceptual model that showcased the relationship between service quality dimensions, destination image, Hallyu, self-congruity, customer satisfaction, attitude, tourism motivation to revisit intention. The conceptual model was developed based on the theory of the SERVQUAL model (Parasuraman et al., 1988) and the SERVPERF model (Cronin \& Taylor, 1992) and MOA (Motivation-opportunity-ability) model (Maclnnis, Moorman \& Jaworski, 1991). Previous researches focused on revisit intention, this conceptual model was modified by applying 13 constructs (see Figure 1).

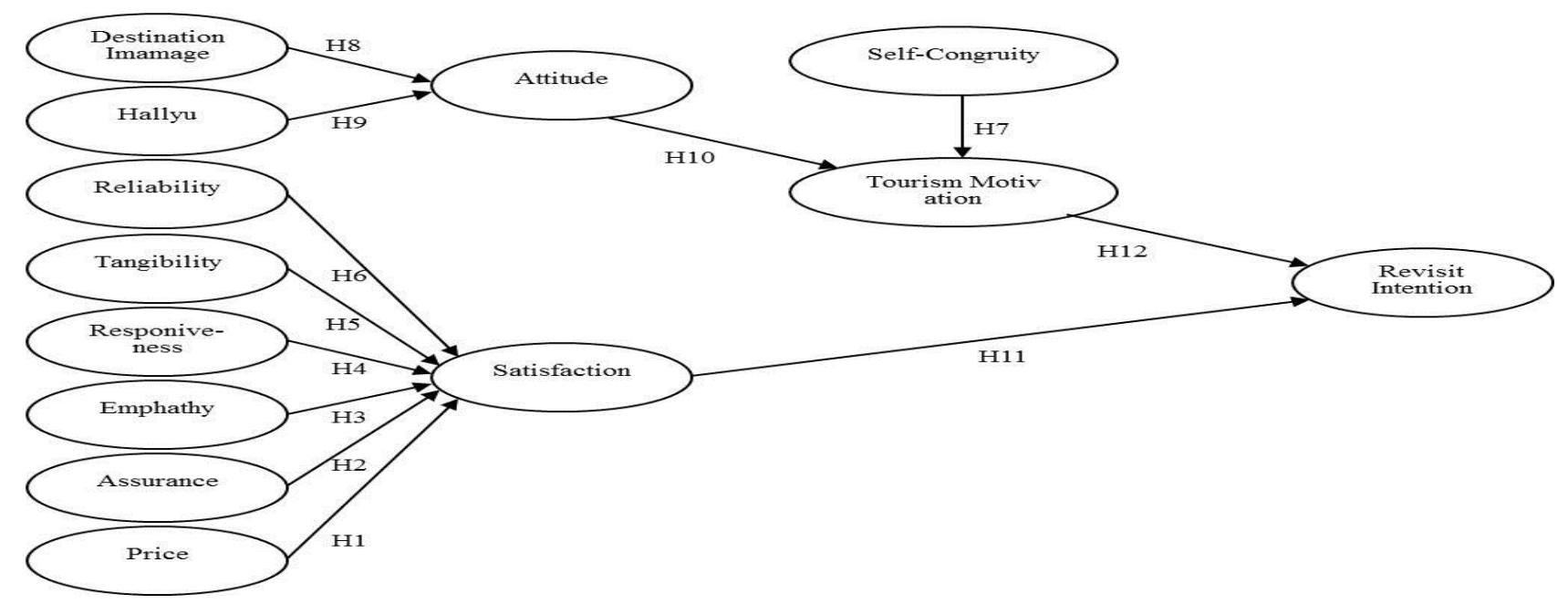

Figure 1: Conceptual Model 


\section{Research Methodology}

The research model was developed on the basis of the hypotheses and needed to be validated empirically using a mixed research method with four phases of the development process. In phase I, 13 constructs in the conceptual model were identified, mainly by a focus group with 9 experts. The focus group discussion consisted of two sections. In section 1, the discussion was based on an extensive literature review. All constructs from the literature review together with those explored in section 1 were incorporated into section 2 . In section 2, a content validity test by CVR (Laewshe, 1975) was designed based on the interview. In phase II, there was an in-depth interview with 19 participants to develop and correct measurement items.

In phase III, the reliability, validity of the measurement items, the final model and hypotheses were tested by an official study with 473 respondents. SEM was used to measure the underlying between observed and latent constructs and test hypotheses. It combined features of factor analysis and multiple regressions for studying both the measurement and the structural properties of theoretical models. For the analysis and testing, SPSS 20 and AMOS 20 software were used. This study applied non-probability with convenience sampling methods. Data was collected using a self-administered questionnaire where the measurement of constructs was based on existing measuring instruments. The questionnaire in this research applied a 5 -point Likert scale $(1=$ strongly disagree; $5=$ strongly agree) and was distributed both electronically using Google form and by questionnaire paper. The Bootstrap model was used for estimating the model parameters for retesting the reliability of the estimates (Schumacker \& Lomax, 2010).

\subsection{Focus Group}

The original conceptual model with 13 constructs was developed from a theoretical basis, previous research was then retested with a focus group discussion. Then 13 constructs were revised. In section 1, all participants agreed with 13 constructs. In section 2, all constructs were tested for content validity by CVR. The result showed 13 constructs were accepted.

\subsection{In-Depth Interview}

The result of the in-depth interview was that 7 measurement items (PR4; PR5; TM4; TM5; TA5; AS5; and SA5) were deleted because their validation $\mathrm{CVR}<0$ was not satisfied. The 58 remaining measurement items then proceeded to an official study.

\subsection{Descriptive Analysis Results}

In the official study, there were 500 respondents, in which 27 invalid responses were eliminated and 473 valid responses were retained for further analysis. The response rate was, therefore, $94.60 \%$. In the aggregate sample, there were 197 males (41,6\%) and 276 females $(58,4 \%), 149$ respondents belonged to Generation Y $(31,5 \%), 324$ of them were Baby Boomers and Generation X (68.5\%). 100\% of respondents had visited Korea. There were 427 tourists $(90.27 \%)$ traveling by groups organized by travel companies and 46 tourists $(9,73 \%)$ traveling on their own.

\section{Empirical Results}

\subsection{Reliability Test}

Cronbach's alpha was a coefficient of reliability. It was commonly used as a measure of internal consistency or reliability of measurement items. A higher Cronbach's alpha coefficient indicated greater reliability and its acceptable lower limit was 0.6 (Nunnally \& Bernstein, 1994). In this research, the Cronbach alpha coefficient of constructs was between 0.656 to 0.920 . Therefore, five measurement items had corrected item-total correlation < $0.3(\mathrm{AT} 3=0.191 ;$ RS5 = 0.128; IR2 = 0.109; IR3 = 0.132; and $\mathrm{EM} 1=0.201)$. They were removed from the study and 53 measurement items remained to go through EFA.

\subsection{Exploratory Factor Analysis}

The measurement items were refined using exploratory factor analysis (EFA) and poorly fitted items were excluded from the study. In this study, an extraction method principal axis factoring with Promax rotation was used. The KaiserMeyer-Olkin measure of sampling adequacy (KMO) = 0.802; Sig. $=0.000$; Extraction Sums of Squared Loadings Cumulative $=57.348 \%$. Pattern Matrix had 13 factors with 53 measurement items (see Table 1). The result of the measurement items, including standardized factor loadings, standard errors, construct reliabilities, and proportions of variance extracted for each construct were presented. Factor loadings of the indicators for each construct were statistically significant and sufficiently high that the indicators and their underlying constructs were accepted. The conceptual model with 13 factors with 53 measurement items was qualified for confirmatory factor analysis. 
Table 1: Pattern Matrix

\begin{tabular}{|c|c|c|c|c|c|c|c|c|c|c|c|c|c|}
\hline & & & & & & & Factor & & & & & & \\
\hline & 1 & 2 & 3 & 4 & 5 & 6 & 7 & 8 & 9 & 10 & 11 & 12 & 13 \\
\hline RE1 & .797 & & & & & & & & & & & & \\
\hline RE2 & .792 & & & & & & & & & & & & \\
\hline RE3 & .744 & . & & & & & & & & & & & \\
\hline RE4 & .728 & & & & & & & & & & & & \\
\hline RE5 & .708 & & & & & & & & & & & & \\
\hline DI4 & & .817 & & & & & & & & & & & \\
\hline DI2 & & .814 & & & & & & & & & & & \\
\hline DI1 & & .671 & & & & & & & & & & & \\
\hline DI3 & & .664 & & & & & & & & & & & \\
\hline DI5 & & .535 & & & & & & & & & & & \\
\hline HA3 & & & .752 & & & & & & & & & & \\
\hline HA4 & & & .696 & & & & & & & & & & \\
\hline HA2 & & & .681 & & & & & & & & & & \\
\hline HA5 & & & .660 & & & & & & & & & & \\
\hline HA1 & & & .642 & & & & & & & & & & \\
\hline TM3 & & & & .973 & & & & & & & & & \\
\hline TM1 & & & & .942 & & & & & & & & & \\
\hline TM2 & & & & .755 & & & & & & & & & \\
\hline EM4 & & & & & .797 & & & & & & & & \\
\hline EM3 & & & & & .757 & & & & & & & & \\
\hline EM5 & & & & & .744 & & & & & & & & \\
\hline EM2 & & & & & .714 & & & & & & & & \\
\hline $\mathrm{SC} 1$ & & & & & & .718 & & & & & & & \\
\hline $\mathrm{SC} 2$ & & & & & & .704 & & & & & & & \\
\hline $\mathrm{SC} 4$ & & & & & & .668 & & & & & & & \\
\hline $\mathrm{SC} 3$ & & & & & & .630 & & & & & & & \\
\hline SC5 & & & & & & .574 & & & & & & & \\
\hline AS2 & & & & & & & .870 & & & & & & \\
\hline AS1 & & & & & & & .795 & & & & & & \\
\hline AS3 & & & & & & & .758 & & & & & & \\
\hline AS4 & & & & & & & .519 & & & & & & \\
\hline PR3 & & & & & & & & .968 & & & & & \\
\hline PR2 & & & & & & & & .943 & & & & & \\
\hline PR1 & & & & & & & & .586 & & & & & \\
\hline AT4 & & & & & & & & & .781 & & & & \\
\hline AT1 & & & & & & & & & .729 & & & & \\
\hline AT2 & & & & & & & & & .714 & & & & \\
\hline AT5 & & & & & & & & & .612 & & & & \\
\hline RS2 & & & & & & & & & & .743 & & & \\
\hline RS3 & & & & & & & & & & .660 & & & \\
\hline RS1 & & & & & & & & & & .638 & & & \\
\hline RS4 & & & & & & & & & & .600 & & & \\
\hline SA1 & & & & & & & & & & & .679 & & \\
\hline SA2 & & & & & & & & & & & .638 & & \\
\hline SA4 & & & & & & & & & & & .610 & & \\
\hline SA3 & & & & & & & & & & & .586 & & \\
\hline TA2 & & & & & & & & & & & & .715 & \\
\hline TA1 & & & & & & & & & & & & .622 & \\
\hline TA4 & & & & & & & & & & & & .556 & \\
\hline TA3 & & & & & & & & & & & & .540 & \\
\hline RI5 & & & & & & & & & & & & & .670 \\
\hline RI4 & & & & & & & & & & & & & .602 \\
\hline RI1 & & & & & & & & & & & & & .567 \\
\hline
\end{tabular}




\subsection{Confirmatory Factor Analysis (CFA)}

The results of confirmative factor analysis (CFA) showed an acceptable fit model: Chi-squared = 1806.442; $\mathrm{df}=1243$; Chi-square $/ \mathrm{df}=1.453 ; \mathrm{P}=0.000 ; \mathrm{GFI}=0.877$; $\mathrm{TFI}=0.945 ; \mathrm{CFI}=0.950 ; \mathrm{IFI}=0.950 ; \mathrm{RMSEA}=0.031$. Although GFI $=0.875$, below 0.9 , but other mode fit indexes were satisfied. All factor loadings of measurement items were $>0.5$ significant. Together, these demonstrated an adequate convergent validity of the measures. Composite reliable and variance extracted were calculated on the basis of standardized weights estimated in the CFA model. Before the hypothesis test, the constructs were tested for two psychometric properties reliability and validity.

Reliability: According to Bagozzi and Kimmel (1995), a factor displayed its reliability if its composite reliability was greater than 0.6. The Cronbach's alpha coefficient retested of all constructs in this study were from 0.656 to 0.920 (see Table 2). Therefore, 13 constructs achieved reliability.

Validity: The research tested validity through both content validity and constructs validity. In terms of content validity, the study used both focus groups and in-depth interviews to test. The result showed that 58 measurement items and constructs achieved content validity. This study checked construct validity both by Composite reliability and AVE. Although variance extracted 2 constructs (SC and TA) weighted nearly 0.5 , the composite reliability of all constructs was 0.743 to 0.927 . Therefore, all constructs were considered to have achieved validity (see Table 2).

Table 2: Construct Test

\begin{tabular}{|c|c|c|c|c|c|}
\hline Construct & Cronbach's Alpha & $\begin{array}{l}\text { Composite } \\
\text { Reliability }\end{array}$ & $\begin{array}{l}\text { Average Variance } \\
\text { Extracted }\end{array}$ & Convergent Validity & Discriminant Validity \\
\hline DI & 0.825 & 0.830 & 0.501 & Accepted & Accepted \\
\hline HA & 0.814 & 0.848 & 0.528 & Accepted & Accepted \\
\hline EM & 0.841 & 0.843 & 0.574 & Accepted & Accepted \\
\hline $\mathrm{SC}$ & 0.786 & 0.824 & 0.486 & Accepted & Accepted \\
\hline AS & 0.820 & 0.852 & 0.544 & Accepted & Accepted \\
\hline AT & 0.813 & 0.811 & 0.514 & Accepted & Accepted \\
\hline $\mathrm{TM}$ & 0.920 & 0.927 & 0.812 & Accepted & Accepted \\
\hline SA & 0.723 & 0.811 & 0.518 & Accepted & Accepted \\
\hline TA & 0.701 & 0.743 & 0.426 & Accepted & Accepted \\
\hline $\mathrm{RS}$ & 0.756 & 0.765 & 0.529 & Accepted & Accepted \\
\hline RI & 0.656 & 0.786 & 0.554 & Accepted & Accepted \\
\hline $\mathrm{RE}$ & 0.865 & 0.866 & 0.564 & Accepted & Accepted \\
\hline PR & 0.863 & 0.883 & 0.723 & Accepted & Accepted \\
\hline
\end{tabular}

Convergent validity can be ensured by assessing discriminant and convergent validity. Measurement items achieved convergence validity if standardized regression weighted $>0.5$ and regression weighted significant $\mathrm{p}<0.05$. The results of this study showed that all standardized regression weights of 53 measurement items were from 0.505 to 0.986 , larger than 0.5 , and p-value of it below 0.05 . Therefore, 53 measurement items were accepted convergent validity.

Discriminant validity. This model of measurement items was consistent and there was no correlation between the measurement error should it achieved unidimensional. The correlation coefficient between constructs with others had to be $<0.9$ or p-value $<0.05$. Therefore 53 measurement items accepted discriminant validity (see Table 2).

\subsection{Structural Equation Modeling (SEM)}

SEM allowed the combination to be the underlying concept with our measurement and could consider the measure independently or in combination with theoretical models at once. In addition, SEM was a comprehensive statistical approach for testing hypotheses about relations between observed and latent variables. It combined features of factor analysis and multiple regressions for studying both the measurement and the structural properties of theoretical models. SEM methodology accounted for independent variable errors and model multiple relationships simultaneously, which resulted in more powerful tests of mean differences.

The first SEM order, parameter RS to SA had p-value = 0.170 and $\mathrm{PR}$ to $\mathrm{SA}=0.150$ more than 0.05 , therefore, it was deleted. Results of second SEM order obtained for 
model showed excellent fit $($ Chi-square $=1527.206 ; \mathrm{df}=$ 954; Chi-square $/ \mathrm{df}=1.601 ; \mathrm{P}=0.00 ; \mathrm{CFI}=0.940 ; \mathrm{IFI}=$ 0.940 ; TLI $=0.935$; GFI $=0.879)$. The RMSEA described the discrepancy between the proposed model and the population covariance matrix. RMSEA $=0.036$, below the recommended 0.08 level (McKnight, Choudhury, \& Kacmar, 2002). Thus, the overall model had a good fit. Therefore, we could proceed to examine the path coefficients of the structural model. The results show that all parameters of 11 constructs in the SEM model for the Pvalue were less than 0.05 so the relationships were significant. All of the constructs were positively correlated (see Table 3).

\subsection{Bootstrap Estimate Model}

This study used methods Maximum Likelihood (ML) to estimate the parameters in the model of SEM. Usually in the quantitative research, so as to test the reliability of the estimates, researchers had to divide it into two samples. The first half was used for estimating the model parameters and the other half was for retesting. The other way was to repeat the study using a different sample and the Bootstrap method (Schumacker \& Lomax, 2010) was suitable. This study used the Bootstrap method with the number of repeated samples $\mathrm{N}=1000$ to test the model in practice. The CR (bias/SE-bias) absolute value was $<2.0$; therefore, the estimates could be trusted and fit.

\subsection{Model Fitting and Hypotheses Testing}

The conceptual model and 12 hypotheses were tested using regression weights in SEM. The results, shown in Table 3, indicated the value of the fit model and that the overall constructs were supported.

There were 10 hypotheses significant and less than the $p$ $<0.05$ level, except for H3 and H6. Overall, all the path coefficient-related hypotheses were supported from 0.129 to 0.329 . It showed that reliability, tangibility, empathy, and assurance positively influenced satisfaction; destination image and Hallyu positively influenced attitude; tourism motivation and satisfaction positively influenced revisit intention. Therefore, 10 hypotheses were accepted and 2 was rejected (see Table 3).

Table 3: Regression Weights (Second-order)

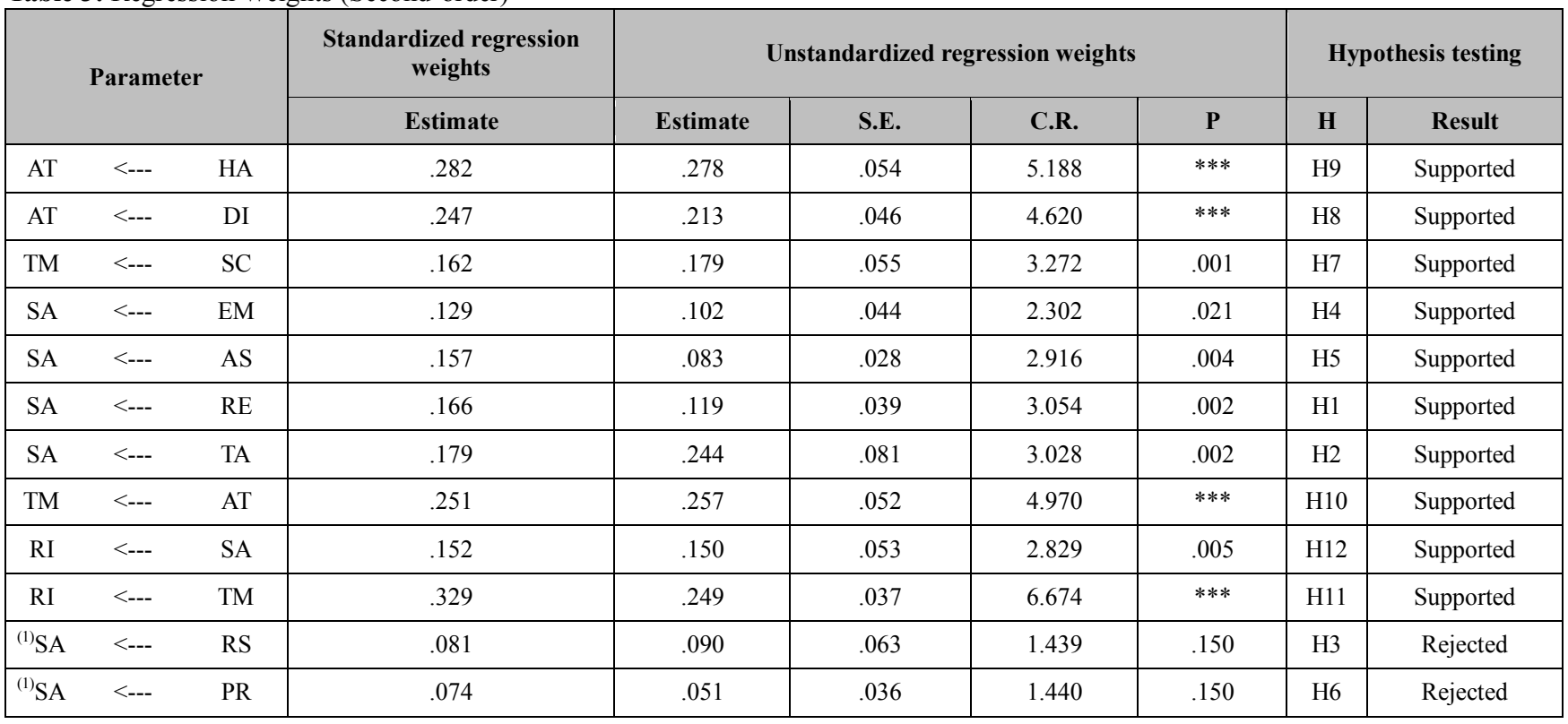

\subsection{Multiple Compare Group}

Respondents were divided into two groups: Male and Female. The structural model was tested across these two groups to determine if the structural paths performed differently across the two groups. To accomplish this, the study followed three steps of invariance testing (Bollen, 1989): (1) a baseline model was first tested with an aggregated sample; (2) the baseline model was then tested separately with each group of sample; and (3) the equivalence of the regression coefficients was tested across the two groups.

The baseline model was then tested separately with Male and Female groups. Both fit model of groups: RMSEA $=0.029 ;$ TLI $=0.915$, CFI $=0.922$, IFI $=0.922$ consistently suggested that the model with different types of gender respectively had an acceptable fit to each sample 
group. This implied a similar factor structure across Male and Female groups. Therefore, the hypothesized model provided a basic structure for the subsequent invariance tests.

The purpose of invariance testing was to find out if regression paths perform equivalently across two groups. If the hypothesis was supported, then the conclusion of an invariant path across the two groups could be made. If the invariance hypothesis was rejected, then regression coefficients were different across groups of testing. The path in the Male group was forced to be invariant to the Female group in the test. The chi-square of the regression path invariance testing model was recorded and was compared to the chi-square obtained in the baseline model. The results suggested that there was statistically a non significant change in chi-square $(\Delta \chi 2=10.393 ; \Delta \mathrm{df}=10)$ and $p$-value $=0.407$. The significant chi-square change indicated that the regression paths were equivalent across Male and Female groups. As such, there was no difference in factors affecting the intention to revisit Korea of male and female Vietnamese groups.

\section{Conclusions and Limitations}

Nowadays, tourism has been a very important economic sector to focus on the global market. This research was developed to find out factors influencing the intention to revisit the Korea of Vietnamese tourists. Based on the findings above, it could be indicated that the quality of services (including empathy, assurance, reliability, and tangibility) impacted tourists' intention to revisit, through satisfaction mediating construct. Destination image, selfcongruity, and Hallyu impacted this intention through attitude and tourism motivation. The path analysis showed that responsiveness and price did not correlate with customer satisfaction. Thus, the conceptual model presented relationships between 10 constructs. The constructs of individual including empathy, assurance, reliability, tangible, self-congruity, destination image, and Hallyu were believed to positively contribute to the level of satisfaction, attitude, and motivation. The hypotheses generated from this model were tested. The 10 of the hypotheses were supported and 2 were rejected.

These results confirmed factors identified by previous research studies. Therefore, Korean tourism firms in particular and those who are based in Vietnam, in general, should take into account the essential roles of the above factors, in order to understand and respond promptly to the demands and expectations of Vietnam visitors. The results of this study can be a valuable source of information for marketing managers to implement strategies and plans, to not only attract more visitors to revisit but also enhance their desires and encourage them to promote to new visitors in Vietnam. One of the important implications of this paper is that Korean firms should take advantage of and increase the destination image, Hallyu, etc. to better reach and motivate the intention to revisit to Korea of Vietnam's visitors.

The limitation is the use of cross-sectional design so it may be influenced at the time of research. These limitations require further research investigation in order to discover the underlying influence of the time series. Another limitation of this research is that it did not yet seek to differentiate between different groups in age, geographic areas, etc. Nevertheless, the topic of revisiting the intention of Vietnamese visitors to Korea is an interesting topic for future research.

\section{References}

Abdullah, S., Razak, A. A., Marzuki, A., \& Jaafar, M. (2017). Assessing tourist satisfaction with the facilities provided at Langkawi island gateway jetty terminals. Liburna, 2(1), 73-92

Aliman, N. K., Mohamed Hashim, S., Mohd Wahid, S. D., \& Harudin, S. (2016). Tourists' Satisfaction with a Destination: An Investigation on Visitors to Langkawi Island. International Journal of Marketing Studies, 8(3), 173-188.

Ananth, A., Ramesh, R., \& Prabaharan, B. (2010). Service quality gap analysis in private sector bank - a customer perspective (MPRA Paper 29505). University Library of Munich, Germany. Retrieved from https://mpra.ub.unimuenchen.de/29505/1/MPRA_paper_29505.pdf

Atilgan, E., Akinci, S., \& Aksoy, S. (2003). Mapping service quality in the tourism industry. Managing Service Quality, 13(5), 412-422.

Backman, S. J., \& Crompton, J. L. (1989). Discriminating between continuers and discontinuers of two public leisure services. Journal of Park and Recreation Administration, 7(4), 56-71.

Bagozzi, R. P., \& Kimmel, S. K. (1995). A comparison of leading theories for the prediction of goal- directed behaviours. British Journal of Social Psychology, 34(4), 437461.

Beerli, A., Meneses, G. D., \& Gil, S. M. (2007). Self-congruity and destination choice. Annals of Tourism Research,34(3), 571-587.

Bollen, K. A. (1989). Structural Equations with Latent Variables. New York, NY: Wiley.

Bowen, D., \& Clarke, J. (2002). Reflections on tourist satisfaction research: Past, present and future. Journal of Vacation Marketing, 8(4), 297-308.

Canny, I. U. (2013). An empirical investigation of service quality, tourist satisfaction and future behavioral intentions among domestic local tourist at Borobudur Temple. International Journal of Trade, Economics and Finance, 4(2), 86. Retrieved from http://www.ijtef.org/papers/265-F603.pdf

Chang, J. C. (2007). Travel Motivations of Package Tour Travelers. Original Scientific Paper, 55(2), 157-176. 
Correia, A., do Valle, P. O., \& Moço, C. (2007). Why people travel to exotic places. International Journal of Culture, Tourism and Hospitality Research, 1(1), 45-61.

Cronin Jr, J. J., \& Taylor, S. A. (1992). Measuring service quality: a reexamination and extension. Journal of Marketing, 56(3), 55-68.

Echtner, C. M., \& Ritchie, J. B. (1993). The measurement of destination image: An empirical assessment. Journal of Travel Research, 31(4), 3-13.

El Saghier, N., \& Nathan, D. (2013). Service quality dimensions and customers' satisfactions of banks in Egypt. Proceedings of 20th international business research conference (Vol. 13). 4-5 April 2013, Dubai, UAE.

Gallarza, M. G., Saura, I. G., \& García, H. C. (2002). Destination image: Towards a conceptual framework. Annals of Tourism Research, 29(1), 56-78.

Gartner, W. C. (1994). Image formation process. Journal of Travel \& Tourism Marketing, 2(2-3), 191-216.

George, R. (2004). Marketing South African Tourism. New York, NY: Oxford University Press.

Gitelson, R. J., \& Crompton, J. L. (1984). Insights into the repeat vacation phenomenon. Annals of Tourism Research, 11(2), 199-217.

Gnoth, J. (1997). Tourism motivation and expectation formation. Annals of Tourism Research, 24(2), 283-304.

Gour, C. S., \& Theingi, S. (2009). Service quality, satisfaction, and behavioural intentions a study of low-cost airline carriers in Thailand. Managing Service Quality, 19(3), 350-372.

Gumussoy, C. A., \& Koseoglu, B. (2016). The effects of service quality, perceived value and price fairness on hotel customers' satisfaction and loyalty. Journal of Economics, Business and Management, 4(9), 523-527.

Gursoy, D., McCleary, K. W., \& Lepsito, L. R. (2007). Propensity to complain: Effects of personality and behavioral factors. Journal of Hospitality \& Tourism Research, 31(3), 358-386.

Herrero, A., San, M, H., \& Collado, J. (2017). Examining the hierarchy of destination brands and the chain of effects between brand equity dimensions. Journal of Destination Marketing \& Management, 6(4), 353-362.

Huang, S., \& Hsu, C. H. (2009). Effects of travel motivation, past experience, perceived constraint, and attitude on revisit intention. Journal of Travel Research, 48(1), 29-44.

Hudson, S., Hudson, P., \& Miller, G. A. (2004). The measurement of service quality in the tour operating sector: a methodological comparison. Journal of Travel Research, 42(3), 305-312.

Jamal, A., \& Goode, M. M. (2001). Consumers and brands: a study of the impact of self-image congruence on brand preference and satisfaction. Marketing Intelligence \& Planning, 19(7), 482-492.

Kim, B.-R. (2015). Past, present and future of Hallyu (Korean Wave). American International Journal of Contemporary Research, 5(5), 154-160.

Kim, H., \& Richardson, S. L. (2003). Motion picture impacts on destination images. Annals of Tourism Research, 30(1), 216237.

Kim, J. H. (2014). The antecedents of memorable tourism experiences: The development of a scale to measure the destination attributes associated with memorable experiences. Tourism Management, 44, 34-45.

Kim, S. (2012). The relationships of on-site film-tourism experiences, satisfaction, and behavioral intentions: The case of Asian audience's responses to a Korean historical TV drama. Journal of Travel \& Tourism Marketing, 29(5), 472484.

Kim, S. Y. (2012). Shopping Motive of Foreign Tourists Influencing Destination Image in Korea: Information type as a moderating variable (Doctor's Thesis). Seojong University Graduate School, Seoul, Korea.

Kim, Y. E., \& Lee, J. W. (2010). Relationship between corporate image and customer loyalty in mobile communications service markets. African Journal of Business Management,4(18), 4035-4041.

Korea Tourism Organization. (2018). Visitor Arrivals. Retrieved January 22, 2019, from http://english.visitkorea.or.kr/enu/index.kto.

Kotler, P., \& Keller, K. L. (2012). Marketing Management $\left(14^{\text {th }}\right.$ ed.). Upper Saddle River, NJ: Prentice-Hall.

Kozak, M. (2001). Repeaters' behavior at two distinct destinations. Annals of Tourism Research, 28(3), 784-807.

Kozak, M., \& Rimmington, M. (2000). Tourist satisfaction with Mallorca, Spain, as an off-season holiday destination. Journal of Travel Research, 38(3), 260-269.

Kressmann, F., Sirgy, M. J., Herrmann, A., Huber, F., Huber, S., \& Lee, D. J. (2006). Direct and indirect effects of self-image congruence on brand loyalty. Journal of Business Research, 59(9), 955-964.

Kumar, M., Kee, F. T., \& Manshor, A. T. (2009). Determining the relative importance of critical factors in delivering service quality of banks. Managing Service Quality: An International Journal, 19(2), 211-228.

Lawshe, C. H. (1975). A quantitative approach to content validity 1. Personnel Psychology, 28(4), 563-575.

Lee, W.-J. (2015). The Effects of the Korean Wave (Hallyu) Star and Receiver Characteristics on TV Drama Satisfaction and Intention to Revisit. International Journal of u-and e-Service, Science and Technology, 8(11), 347-356.

Leiper, N. (1979). The framework of tourism: Towards a definition of tourism, tourist, and the tourist industry. Annals of Tourism Research, 6(4), 390-407.

Luo, Y., \& Deng, J. (2008). The New Environmental Paradigm and nature-based tourism motivation. Journal of Travel Research, 46(4), 392-402.

Maclnnis, D. J., Moorman, C., \& Jaworski, B. J. (1991). Enhancing and measuring consumers' motivation, opportunity, and ability to process brand information from ads. Journal of Marketing, 55(4), 32-53.

March, R., \& Woodside, A. G. (2005). Tourism behavior: Travellers decisions and actions. Wallingford, UK: CABI Publishing.

McKnight, D. H., Choudhury, V., \& Kacmar, C. (2002). Developing and validating trust measures for e-commerce: An integrative typology. Information Systems Research, 13(3), 334-359.

Mill, R. C., \& Morrison, A. M. (1985). The Tourism System. Englewood Cliff, NJ: Prentice-Hall.

Nguyen, X. T. (2018). The Impact of Hallyu 4.0 and Social Media 
on Korean Products Purchase Decision of Generation C in Vietnam. Journal of Asian Finance, Economics, and Business, 5(3) 81-93. http://doi.org/10.13106/jafeb.2018.vol5.no3.81.

Nguyen, X. T. (2019). Factors impacting on Korean consumer goods purchase decision of Vietnam's generation Z. Journal Distribution Science, 17(10), 61-71.

Nguyen, M. H., Dang, L. A. T., \&, Ngo, T. T. (2019). The Effect of Local Foods on Tourists' Recommendations and Revisit Intentions: The Case in Ho Chi Minh City, Vietnam. Journal of Asian Finance, Economics and Business. 6(3), 215223. https://doi.org/10.13106/jafeb.2019.vol6.no3.215

Noh, J., Lee, K. W., \& Hwang, J. (2017). The effect of motivational factor for using SNSs on tourist attitude. Tourism and Hospitality Management, 23(2), 185-194.

Nunnally, J. C. (1994). Psychometric theory (3 ${ }^{\text {rd }}$ ed.). Mumbai, India: Tata McGraw-Hill Education.

Parasuraman, A., Zeithaml, V. A., \& Berry, L. L. (1988). Servqual: A multiple-item scale for measuring consumer perc. Journal of Retailing, 64(1), 12-40.

Phau, I., Quintal, V., \& Shanka, T. (2014). Examining a consumption values theory approach of young tourists toward destination choice intentions. International Journal of Culture, Tourism and Hospitality Research, 8(2), 125-139.

Phillips, W. J., Asperin, A., \& Wolfe, K. (2013). Investigating the effect of country image and subjective knowledge on attitudes and behaviors: US Upper Midwesterners' intentions to consume Korean Food and visit Korea. International Journal of Hospitality Management, 32, 49-58.

Phillips, W., \& Jang, S. (2007). Destination image and visit intention: Examining the moderating role of motivation. Tourism Analysis, 12(4), 319-326.

Pike, S., \& Page, S. J. (2014). Destination Marketing Organizations and destination marketing: A narrative analysis of the literature. Tourism Management, 41, 202-227.

Pusiran, A. K., \& Xiao, H. (2013). Challenges and community development: A case study of homestay in Malaysia. Asian Social Science, 9(5), 1-17.

Sampol, C. J. (1996). Estimating the probability of return visits using a survey of tourist expenditure in the Balearic Islands. Tourism Economics, 2(4), 339-351.

San Martín, H., \& Del Bosque, I. A. R. (2008). Exploring the cognitive-affective nature of destination image and the role of psychological factors in its formation. Tourism Management, 29(2), 263-277.

Sanchez, J., Callarisa, L., Rodriguez, R. M., \& Moliner, M. A. (2006). Perceived value of the purchase of a tourism product. Tourism Management, 27(3), 394-409.

Schumacker, R. E., \& Lomax, R. G. (2010). A Beginner's Guide to. Structural Equation Modeling (3rd ed.). New York, NY: Taylor \& Francis Group.
Severt, D., Wang, Y., Chen, P. J., \& Breiter, D. (2007). Examining the motivation, perceived performance, and behavioral intentions of convention attendees: Evidence from a regional conference. Tourism Management, 28(2), 399-408.

Sirgy, M. J. (1982). Self-concept in consumer behavior: A critical review. Journal of Consumer Research, 9(3), 287-300.

Sirgy, M. J., \& Su, C. (2000). Destination image, self-congruity, and travel behavior: Toward an integrative model. Journal of Travel Research, 38(4), 340-352.

Sriyam, A. (2010). Customer satisfaction towards service quality of front office staff at the hotel (Master Thesis). Srinakharinwirot University, Bangkok, Thailand.

Sung, H.-Y., Kim, J.-J., \& Youn, M.-K. (2014). A Study upon Effects of Family Restaurant Consumption Values upon Satisfaction, Reliability and Behavioural Intentions in Korea: Focused on College Students at Metropolitan Area. Journal of Asian Finance, Economics and Business, 1(4), 29-37. https://doi.org/10.13106/jafeb.2014.vol1.no4.29.

Um, S., Chon, K., \& Ro, Y. (2006). Antecedents of revisit intention. Annals of Tourism Research, 33(4), 1141-1158.

Urry, J. (1990). Leisure and travel in contemporary societies. London, UK: Sage Publications.

Usakli, A., \& Baloglu, S. (2011). Brand personality of tourist destinations: An application of self-congruity theory. Tourism Management, 32(1), 114-127.

Venkatesh, U. (2006). Leisure-meaning and impact on leisure travel behavior. Journal of Services Research, 6(1), 87-108.

Wang, Y. J., Wu, C., \& Yuan, J. (2010). Exploring visitors' experiences and intention to revisit a heritage destination: The case for Lukang, Taiwan. Journal of Quality Assurance in Hospitality \& Tourism, 11(3), 162-178.

Williams, P., \& Soutar, G. N. (2009). Value, satisfaction and behavioral intentions in an adventure tourism context. Annals of Tourism Research, 36(3), 413-438.

Wirtz, J., \& Lovelock, C. (2016). Services marketing: People, technology. Singapore: World Scientific Publishing Company.

Yieh, K., Chiao, Y. C., \& Chiu, Y. K. (2007). Understanding the antecedents to customer loyalty by applying structural equation modeling. Total Quality Management \& Business Excellence, 18(3), 267-284.

Yoon, Y., \& Uysal, M. (2005). An examination of the effects of motivation and satisfaction on destination loyalty: a structural model. Tourism Management, 26(1), 45-56.

Yu, H., Kim, C., \& Kim, H. (2012). Investigating cosmetics purchase of international tourists in South Korea. International Journal of Management Cases, 14(1), 398-410.

Zeithaml, V. A., Bitner, M. J., \& Gremler, D. D. (2006). Services Marketing: Intergation Customer Focus across. New York, NY: McGrew Hill. 